\title{
Performance and physiology of large containerized and bare-root spruce seedlings in relation to scarification and competition in Québec (Canada)
}

\author{
Nelson ThiFfaulT ${ }^{\mathrm{a}, \mathrm{b} *}$, Robert JoBIDON ${ }^{\mathrm{b}}$, Alison D. MunsON ${ }^{\mathrm{a}}$ \\ ${ }^{\text {a }}$ Centre de recherche en biologie forestière, Faculté de foresterie et de géomatique, Université Laval, Sainte-Foy, QC, G1K 7P4 Canada \\ ${ }^{\mathrm{b}}$ Ministère des Ressources naturelles, de la Faune et des Parcs, Direction de la recherche forestière, 2700 rue Einstein, Sainte-Foy, QC, G1P 3W8 Canada
}

(Received 24 June 2002; accepted 17 March 2003)

\begin{abstract}
In Québec (Canada), the use of large planting stock is being applied in combination with scarification, since herbicide use is forbidden in public forest. Large containerized and bare-root stock of black spruce were planted on two sites located within the sub-boreal mixedwood region of eastern Québec. We analyzed data to detect main effects and interactions among scarification, competing vegetation and stock type on seedling growth and physiology during the first three growing seasons. Scarification did not improve seedling water relations, third-year height and ground-level diameter, and foliar nutrient concentration. After three years, the two stock types showed similar water relations and nutritional status but the large containerized seedlings performed slightly better than the large bare-root stock in terms of diameter and height growth. Competing vegetation greatly reduced seedling diameter, foliar-N concentration, compared to competition-free seedlings. We discuss results in relation with treatment effects on above- and belowground resource availability to newly planted conifers.
\end{abstract}

scarification / competing vegetation / large seedling / growth / xylem water potential

Résumé - Performance et physiologie de plants de fortes dimensions d'épinette produits en récipients et à racines nues en relation avec le scarifiage et la végétation compétitive au Québec (Canada). Au Québec (Canada), l'utilisation de phytocides chimiques est proscrite en forêt publique. Le reboisement de plants de fortes dimensions (PFD) est pratiqué, en combinaison avec le scarifiage, sur les stations à haut risque de compétition. Des PFD d'épinette noire en récipients (RC) et à racines nues (RN) ont été plantés sur deux sites afin d'évaluer les effets du scarifiage, de la compétition, du type de plant et de leurs interactions sur l'établissement des plants pendant les trois premières saisons de croissance. Le scarifiage n'a pas d'effet marqué sur les dimensions et la physiologie des semis après trois ans. Les deux types de PFD présentent, après trois saisons, des relations hydriques et des statuts nutritifs équivalents. Les RC atteignent des dimensions légèrement supérieures à celles des RN. La végétation a peu d'impacts sur la croissance en hauteur, mais affecte négativement le diamètre et le statut nutritif. Nous discutons des résultats à l'égard de leurs effets sur la disponibilité des ressources environnementales pour les plants.

scarifiage / végétation compétitive / plant de fortes dimensions / croissance / potentiel hydrique du xylème

\section{INTRODUCTION}

Chemical vegetation control is an important silvicultural operation performed in young plantations to ensure growth and survival of planted conifers. However in recent years, the use of chemical herbicides has become less acceptable to the public [60]. In Québec (Canada), alternative competing vegetation management strategies are currently being investigated, since chemical herbicides are forbidden on public land [35]. These strategies recommend that sites prone to severe competition should be scarified and planted with large conifer stock the year after final harvest. This short delay between final harvest and plantation is expected to modify competing vegetation dynamics, compared to scarification of sites that are already invaded by competitors.
Soil scarification treatments are generally known to improve planted conifer seedling growth and survival during the establishment phase $[3,12,16]$. Beneficial effects of soil scarification are associated with increased soil temperature and water availability, enhanced mineralization rates, and decreased competing vegetation density [43]. The effects of scarification on vegetation growth are highly variable, depending on site characteristics and scarification intensity [18]. Early successional species can easily propagate by root cutting or suckering [17, 23]. The emergence of new stems can thus be stimulated by root sectioning after soil scarification [22]. Moreover, owing to their nitrophilous nature $[2,20]$, these species can take advantage of the site conditions prevailing after soil scarification.

Soil scarification by disc trenching is commonly used in Québec to prepare mixedwood sites for conifer plantation.

\footnotetext{
*Corresponding author: nelson.thiffault@ mrnfp.gouv.qc.ca
} 
Much of the research concerning effects of scarification on soil characteristics and vegetation dynamics was carried out on boreal sites characterized by thick humus layers (e.g. [49]), or has involved high-intensity treatments such as complete humus removal by scalping (e.g. [38]). More specific knowledge about the effects of scarification on soil properties and competing vegetation of sites characterized by thin humus layers is still needed [48].

Competing vegetation can represent a threat to successful establishment and growth of conifer plantations [61]. Competition for water, nutrients and light are the main factors responsible for reduced growth [8], their relative importance varying according to site characteristics. In the sub-boreal mixedwoods sites of Québec prone to invasion by competing vegetation after major disturbance, light was identified as the main limiting environmental resource to planted conifer growth [21, 24]. Vegetation can also compete with planted conifers for nutrients [44] and alter the soil thermal regime [6, 24].

The use of large conifer stock that can overcome competition by non-crop species has potential [39], and is currently part of the regeneration strategy in the province of Québec [35]. In recent studies, Jobidon et al. [25] and Lamhamedi et al. [28] demonstrated that large containerized seedlings of black spruce [Picea mariana (Mill.) B.S.P.] can be planted on a variety of reforestation sites without experiencing lethal water stress. Planting bare-root or containerized spruce stock types could play a significant role in the success of plantation establishment [33]. These stock types generally differ in their water relations during the first few years after planting; bare-root seedlings generally experience greater planting stress than containerized seedlings $[1,40]$. This greater stress is attributed to the reduced root system permeability of bare-root stock, compared to containerized stock [15] and desiccation or injury to roots during planting activities [27]. Stock type, scarification, and vegetation can interact to influence plantation success [10, 29, 62]. There is a need to investigate these potential interactions in the new forest regeneration strategy implemented in Québec.

Our objectives were to evaluate how soil scarification, competing vegetation, and stock type act solely or interact to influence third-year dimensions, nutrition, and transplanting shock of large stock of black spruce seedlings, in cases where scarification and planting are performed the year following final harvest. Also, we examined the influence of scarification, competing vegetation, and their interactions on soil temperature, water content, and nutrient availability. We designed the experiment to test the following hypotheses. First, we hypothesized that the large bare-root seedlings experience a stronger water stress than the large containerized stock, and that the latter present better growth and nutrition than the former. Secondly, we expected soil scarification to benefit to planted seedling establishment by increasing soil temperature, water content, and nutrient availability. Thirdly, we expected competition by non-crop vegetation to have the strongest impact on seedling growth and nutrition, for both the large containerized and bare-root stock. Finally, we hypothesized that the presence of competition has a negative impact on surface soil temperature, depletes soil water content, and reduces nutrient availability to planted seedlings.

\section{MATERIALS AND METHODS}

\subsection{Study site}

We established two experimental plantations, Ruisseau Plourde (named as RP; latitude $47^{\circ} 46^{\prime} 25^{\prime \prime} \mathrm{N}$, longitude $68^{\circ} 25^{\prime} 45^{\prime \prime} \mathrm{W}$ ) and Lac Castor (named as LC; latitude $47^{\circ} 53^{\prime} 05^{\prime \prime} \mathrm{N}$, longitude $68^{\circ} 26^{\prime}$ $35^{\prime} \mathrm{W}$ ), both located in eastern Québec within the balsam fir [Abies balsamea (L.) Mill.] - yellow birch [Betula alleghaniensis Britt.] bioclimatic domain [52], about $350 \mathrm{~km}$ east of Québec city. The regional climate is described as sub-humid continental with total annual precipitation between 1000 and $1100 \mathrm{~mm}$ and a mean annual temperature of $2.5^{\circ} \mathrm{C}$ [50]. Prior to harvest, both sites were mature stands composed mainly of balsam fir, white spruce $[P$. glauca (Moench) Voss] and yellow birch. The soil of RP is a deep loam-textured till, moderately well-drained, classified as an orthic humo-ferric podzol [54]. The surface mineral soil (upper B horizon; 0-0.15 m) contained $34 \%$ sand $(50-2000 \mu \mathrm{m}), 42 \%$ silt $(5-50 \mu \mathrm{m})$, and $24 \%$ clay $(<5 \mu \mathrm{m})$. The soil of LC is a deep clay-loam-textured till, imperfectly-drained, classified as a podzolic luvisol [54]. The surface soil contained $37 \%$ sand, $47 \%$ silt, and $26 \%$ clay. Both soil profiles were characterized by a mor humus layer of $3 \mathrm{~cm}$. Experimental sites RP and LC were clearcut-harvested in the summers of 1996 and 1997, respectively, and prepared with brush rakes the following fall. Major pioneer species established on the sites in the following years were red raspberry [Rubus idaeus L.], bracken fern [Pteridium aquilinum (L.) Kuhn.], fireweed [Epilobium angustifolium L.], pin cherry [Prunus pensylvanica L.], and mountain maple [Acer spicatum Lam.] at $\mathrm{RP}$, and red raspberry, goldenrod [Solidago rugosa Ait.], fireweed, fly-honeysuckle [Lonicera canadensis Bartr.], and willow [Salix spp.] at LC. There was no competing vegetation on the sites at time of planting.

\subsection{Experimental design and treatments}

At both RP and LC, a split-block factorial design was applied, with scarification and competing vegetation treatments in strips [56], and stock types added as an additional split within each scarification $\times$ competing vegetation combination (Fig. 1). Soil scarification was carried out in September 1996 and September 1997 for experimental sites RP and LC, respectively, and included two treatments: (i) no scarification and (ii) soil scarification with a TTS disc trencher. Scarification consisted in removal and deposition of the organic layer and some underlying mineral soil in berms beside the trench. In each of the nine blocks of RP and 10 blocks of LC, we randomly assigned the two scarification treatments to one half of the block, forming two $10 \mathrm{~m} \times 62 \mathrm{~m}$

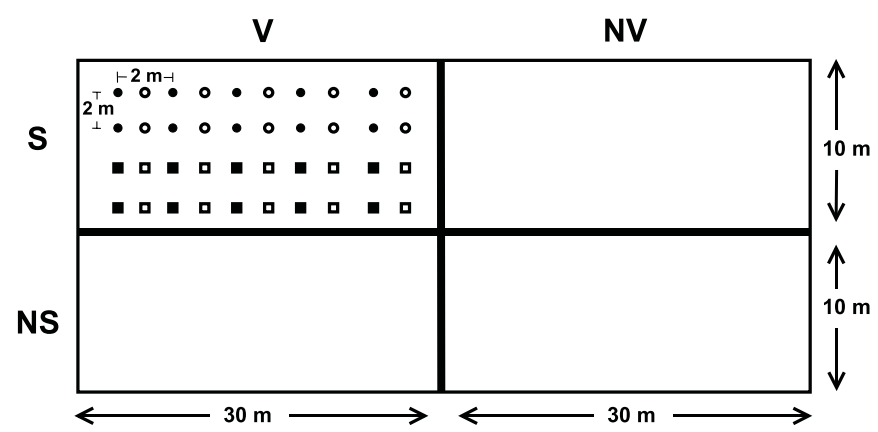

Figure 1. Experimental design: example of one complete block, with details of one subplot. $\mathrm{S}=$ with scarification; $\mathrm{NS}=$ no scarification; $\mathrm{V}=$ with vegetation; $\mathrm{NV}=$ no vegetation; $\bullet=$ numbered containerized seedling; $\mathrm{O}=$ non-marked containerized seedling; $\boldsymbol{\square}=$ numbered bare-root seedling; $\square=$ non-marked bare-root seedling. 
main plots separated by a $2-\mathrm{m}$ buffer. We split blocks perpendicularly to the scarification plots into two $30 \mathrm{~m} \times 22 \mathrm{~m}$ plots separated by a 2 -m buffer. To adequately quantify the effects of non-crop vegetation, we carried out complete and continuous control of competing vegetation in one randomly chosen half of each block, in strips physically crossing the scarification whole plots, thus forming four subplots. We achieved control of competing vegetation by repeated glyphosate applications (1.5\% v:v in water; Sept. 1998 and Aug. 1999 at RP; Sept. 1999 and Sept. 2000 at LC). When needed, we covered seedlings with thick rubber cones to avoid herbicide contact. We also carried out manual control treatments with brushsaws and manual cutters periodically during the first three growing seasons on both sites.

Two large stock types of black spruce were obtained from the provincial nursery of Saint-Modeste, Québec. Large containerized seedlings (seed source for RP: latitude $47^{\circ} 30^{\prime} \mathrm{N}$, longitude $69^{\circ} 10^{\prime} \mathrm{W}$; seed source for LC: latitude $47^{\circ} 00^{\prime} \mathrm{N}$, longitude $75^{\circ} 10^{\prime} \mathrm{W}$ ) were grown over two years $(2+0)$ in air-slit containers with $350-\mathrm{cm}^{3}$ cavities developed by the Ministère des Ressources naturelles du Québec [13]. For this type of production, seedlings are raised in a tunnel during the first season, before being installed outside, where they pass the next winter and summer. Large bare-root seedlings (seed source for RP: latitude $47^{\circ} 10^{\prime} \mathrm{N}$, longitude $69^{\circ} 40^{\prime} \mathrm{W}$; seed source for LC: latitude $47^{\circ} 40^{\prime} \mathrm{N}$, longitude $69^{\circ} 10^{\prime} \mathrm{W}$ ) were grown outside in planting beds for four years $(2+2)$. After planting, we measured all seedlings for total height and ground level diameter (GLD). Bare-root stock was on average the same height than container stock $(38 \mathrm{~cm})$, but had a larger GLD (by $1.3 \mathrm{~mm}$ ). Large bare-root seedlings had an initial total aboveground dry biomass two times that of large containerized seedlings (measured on a sub-sample of $n=60$, dried at $65^{\circ} \mathrm{C}$ for $48 \mathrm{~h}$ ).

Seedlings were planted in June 1997 and June 1998 at RP and LC, respectively. To standardize root moisture among seedlings at time of planting, we immersed the root plug or root system of each large containerized and bare-root seedling in water immediately before transplanting, thus favouring high initial water potential and stimulating the immediate onset of photosynthesis [8]. Within each subplot, we planted 20 seedlings of each stock type at a $1 \mathrm{~m} \times 2 \mathrm{~m}$ spacing, with seedlings of the same stock type placed in adjacent rows (Fig. 1). Destructive measurements performed over the first three years (see below) resulted in a $2 \mathrm{~m} \times 2 \mathrm{~m}$ spacing at the end of the third growing season, thus avoiding any potential intra-specific competition effects. We also planted white and Norway [P. abies (L.) Karst] spruce seedlings, but results reported here only focus on black spruce. In scarified plots, seedlings were planted on the top edge of trenches, as close to the humus edge as possible, according to the recommendations of Örlander et al. [43].

\subsection{Seedling measurements}

On both sites, half of the planted seedlings were identified using $30-\mathrm{cm}$ high steel-pegs planted nearby. We used these marked seedlings for height $(\mathrm{cm})$, GLD $(\mathrm{mm})$, and survival measurements at the end of the third growing season (Fig. 1).

On both sites, we assessed the competitive status of one out of two marked seedlings planted in the subplots with competing vegetation in July of the third growing season (that is July 1999 and July 2000 for RP and LC, respectively), following the procedure described by Jobidon [19]. Competitive status was evaluated by mean of the photosynthetic active radiation (PAR) reaching the mid-upper crown of the seedling at time of maximum vegetation canopy development. Light measurements were performed using a Sunfleck ceptometer (Decagon Devices, Pullman, WA). Average upper-crown readings are expressed as a percentage of above-canopy light level (\% PAR). We carried out surveys of competing vegetation density on both sites in mid-July of the third growing season, using two $0.8-\mathrm{m}$ radius $\left(2 \mathrm{~m}^{2}\right)$ vegetation sample plots within each subplot containing competing vegetation. For further analysis, we classified competing spe- cies into the following categories: Rubus, Epilobium, Ferns, Prunus, Acer, Other trees, and Others.

Only non-marked seedlings were used for the following destructive measurements. At the end of the third growing season (October) on both sites, we excised current-year shoots for foliar-nutrient concentration determination. One composite sample from three seedlings in each soil scarification $\times$ competing vegetation $\times$ stock type combination was collected in each block of both sites. After collection, we stored samples frozen until chemical analysis. Prior to analysis, material was oven-dried at $65{ }^{\circ} \mathrm{C}$ for $48 \mathrm{~h}$ and ground to pass a 40-mesh screen. After $\mathrm{H}_{2} \mathrm{O}_{2} / \mathrm{Se}$ digestion [45], total $\mathrm{N}$ was measured colorimetrically by spectrophotometry (FIA Quickchem, Lachat, Milwaukee, WI) and P, K, Ca, Mg by inductively coupled plasma analysis (ICAP-9000, Thermo Instruments, Franklin, MA).

We measured predawn (3h00) and midday (13h00) black spruce xylem water potentials (XWP) periodically at RP and LC during the first three growing seasons. We performed measurements using a portable pressure chamber (PMS Instruments, Corvallis, OR) on seedlings planted in scarified and unscarified subplots containing competing vegetation. At the time of each measurement, a one-yearold shoot was excised from a randomly selected containerized and bare-root seedling within the selected plots of nine blocks. Thus, a total of 36 measurements were performed at each sampling event. Cut shoots were immediately placed in a paper bag to avoid direct sunlight and limit water loss. We measured seedling XWP within 20 min of excision.

\subsection{Environmental monitoring}

At both sites, we monitored soil temperature (10-cm depth) and volumetric soil water content (first $15 \mathrm{~cm}$ ) on a continuous basis in four subplots of each scarification $\times$ competing vegetation combination, from early June to early November of the first three growing seasons. Soil temperature and volumetric soil water content (SWC) were measured with a thermistor (Temperature probe Model 107BAM, Campbell Sci., Logan, UT) and a CS615 Water Content Reflectometer (Campbell Sci., Logan, UT), respectively. In scarified plots, probes were placed at the top edge of trenches, as close to the humus edge as possible. Data were hourly averaged and recorded using a CR-10 data logger (Campbell Sci., Logan, UT).

\subsection{Measurement of nutrient availability}

We assessed soil nutrient availability with use of mixed-bed exchange resins (IONAC NM-60 $\mathrm{H}^{+} / \mathrm{OH}^{-}$, J.T. Baker, Phillipsburg, $\mathrm{NJ})$. Resins were washed [58] and placed in squares of nylon polyester fabric $(8 \mathrm{~cm} \times 8 \mathrm{~cm})$ sewed and heat sealed $\left(15 \mathrm{ml} \mathrm{resin} \mathrm{bag}^{-1}, 50 \%\right.$ weight-based humidity, $0.27 \mathrm{~g} \mathrm{ml}^{-1}$ of resins, dry weight). Bags were rinsed in deionised water and stored moist and cold (around $5^{\circ} \mathrm{C}$ ) until burial in the soil. In late May or early June of the first three growing seasons, we buried five resin bags in each scarification $\times$ competing vegetation combination of six and seven randomly chosen blocks of RP and LC, respectively. Bags were buried flat at 10-cm depth in scarified plots (top edge of trenches) or $10 \mathrm{~cm}$ below the mineral-organic boundary in unscarified plots. We distributed and flagged placement sites evenly within each subplot. Every sampling season (1997, 1998, 1999 , and 2000), forty bags were buried in an uncut mixedwood fores stand located nearby (about $200 \mathrm{~m}$ ) the RP site (for non statistical comparative purposes only). This stand was composed of balsam fir, black and white spruce, and trembling aspen [Populus tremuloides Michx.]. The stand had similar soil characteristics than the experimental layout, except for the humus layer that was thicker (10$15 \mathrm{~cm})$. We recovered resin bags in late October of each season and stored them moist and cold (around $5{ }^{\circ} \mathrm{C}$ ) until nutrient extraction. Adsorbed ions were extracted in a $2 \mathrm{~N}$ sodium chloride solution and analysis was performed as described above. 


\subsection{Statistical analyses}

We did not statistically compare experimental sites. At each site, the experiment was considered as a strip-split-split-block design [56], with the soil scarification treatment applied in the main plot and the competing vegetation treatment applied in the subplot. Stock type was considered as an additional split within each subplot. We determined the effect of treatments on the measured variables by ANOVAs using the MIXED procedure of the SAS 8.01 software (SAS Institute inc., Cary, NC). We used a Fisher's protected LSD test [56] to separate treatment means in the case of a significant $p$-value $(p<$ $0.05)$ after the $F$-test of the ANOVA. For both sites, ANOVA for a split-plot design was used to detect the effect of soil scarification (main plot) and stock type (subplot) on the competitive status of seedlings. To detect the scarification, stock type and time (date within the season) effects on predawn and midday XWP of the seedlings, data were analyzed by ANOVA, as a split-split-plot in time design [56]. We considered soil scarification treatment as the whole-unit treatment, stock type as the subunit treatment, and time as the sub-subunit treatment. For analysis of seasonal soil temperature sums (sum of degree-day above $5^{\circ} \mathrm{C}$ ) and nutrient sorption by resins, we considered the experiment as a strip-split-block design [56], with the scarification treatment applied in the main plot and the competing vegetation treatment applied in the subplot. Soil temperature and SWC seasonal profiles were submitted to analysis of variance for repeated measurements (ANOVAR) to detect scarification, vegetation, and time effects. We separately analyzed data from the three growing seasons. We used the CORR procedure of SAS to calculate Pearson correlation coefficients $(r)$ and their associated $p$-value among stem densities (counts) of vegetation categories at both experimental sites. Since most of the variables were uncorrelated or had low $r$ in the case of significant correlation, we used ANOVA for completely rand- omized block designs to detect the effect of scarification on density separately for each of the vegetation categories [53].

We tested all data for normality and homoscedasticity of the experimental errors. In the case of departure from normality or of heterogeneous variances, data were transformed, and ANOVAs were performed on transformed data. When these analyses gave results comparable to those of the ANOVAs performed on untransformed data, we retained the results obtained from untransformed data since sample sizes were nearly equal and the $F$-test is robust in the presence of unequal variances in this case [34]. Text, tables and figures therefore describe only original (untransformed) data, with the exception of nutrient availability and stem density data that were natural-log and square-root transformed, respectively. For these variables, text and figures describe back-transformed data, with confidence limits $( \pm 2 \mathrm{SE})$ computed by back-transforming confidence limits of the means computed on the transformed scales.

\section{RESULTS}

\subsection{Third-year height and survival}

At both sites, third-year seedling total height was not or only weakly influenced by soil scarification (Tab. I). Even in the case of significant interaction between scarification and stock type (LC), and scarification, vegetation, and stock type (RP), the single effects of soil scarification and competing vegetation were marginal. At both sites, stock type interacted with other treatments. At RP, detailed analysis of the interaction between scarification, competing vegetation and stock type revealed that large container-grown black spruce was

Table I. Third-year total height of containerized and bare-root black spruce seedlings planted at Ruisseau Plourde (RP) and Lac Castor (LC) with or without scarification and with or without competing vegetation.

\begin{tabular}{|c|c|c|c|}
\hline \multicolumn{2}{|c|}{$\mathrm{RP}$} & \multicolumn{2}{|c|}{$\mathrm{LC}$} \\
\hline Treatment & Height (cm) & Treatment & Height $(\mathrm{cm})$ \\
\hline With vegetation & & Vegetation & \\
\hline Containerized - scarified & $93.2(1.8) \mathrm{a}$ & With & $84.5(2.0) \mathrm{a}$ \\
\hline Bare-root - scarified & $82.0(1.8) b$ & Without & $88.0(2.0) \mathrm{a}$ \\
\hline Containerized - unscarified & $91.2(1.8) \mathrm{a}$ & & \\
\hline \multirow[t]{2}{*}{ Bare-root - unscarified } & $85.4(1.8) \mathrm{b}$ & With scarification & \\
\hline & & Containerized & $83.1(2.1) \mathrm{a}$ \\
\hline Without vegetation & & Bare-root & $84.7(2.1) \mathrm{a}$ \\
\hline Containerized - scarified & $93.8(1.8) \mathrm{ab}$ & & \\
\hline Bare-root - scarified & $93.8(1.8) \mathrm{ab}$ & Without scarification & \\
\hline Containerized - unscarified & $97.7(1.8) \mathrm{a}$ & Containerized & $91.0(2.0) \mathrm{a}$ \\
\hline Bare-root - unscarified & $90.4(1.8) \mathrm{b}$ & Bare-root & $86.3(2.0) b$ \\
\hline ANOVA (fixed effects) & & ANOVA (fixed effects) & \\
\hline Scarification (S) & $p=0.577$ & Scarification $(\mathrm{S})$ & $p=0.042$ \\
\hline Vegetation (V) & $p<0.001$ & Vegetation (V) & $p=0.232$ \\
\hline $\mathrm{S} \times \mathrm{V}$ & $p=0.880$ & $\mathrm{~S} \times \mathrm{V}$ & $p=0.417$ \\
\hline Stock type $(\mathrm{T})$ & $p<0.001$ & Stock type (T) & $p=0.317$ \\
\hline $\mathrm{S} \times \mathrm{T}$ & $p=0.643$ & $\mathrm{~S} \times \mathrm{T}$ & $p=0.046$ \\
\hline $\mathrm{V} \times \mathrm{T}$ & $p=0.077$ & $\mathrm{~V} \times \mathrm{T}$ & $p=0.118$ \\
\hline $\mathrm{S} \times \mathrm{V} \times \mathrm{T}$ & $p<0.001$ & $\mathrm{~S} \times \mathrm{V} \times \mathrm{T}$ & $p=0.916$ \\
\hline
\end{tabular}

Data are presented as MEAN (SE). For a given combination of treatments with respect to each site, means followed by the same letter are not significantly different, according to the Fisher's protected LSD test. 
Table II. Third-year ground level diameter (GLD) of containerized and bare-root black spruce seedlings planted at Ruisseau Plourde (RP) and Lac Castor (LC) with or without scarification and with or without competing vegetation.

\begin{tabular}{lcc}
\hline \multirow{2}{*}{ Treatment } & \multicolumn{2}{c}{ GLD (mm) } \\
\cline { 2 - 3 } & \multicolumn{2}{c}{$\mathrm{RP}$} \\
\hline Scarification & $21.9(0.4) \mathrm{a}$ & $16.7(0.4) \mathrm{a}$ \\
$\quad$ With & $22.4(0.4) \mathrm{a}$ & $17.6(0.4) \mathrm{b}$ \\
$\quad$ Without & & \\
Vegetation & $16.5(0.4) \mathrm{a}$ & $13.9(0.5) \mathrm{a}$ \\
$\quad$ With & $27.8(0.4) \mathrm{b}$ & $20.4(0.5) \mathrm{b}$ \\
$\quad$ & \\
$\quad$ Without & & \\
Stock type & $22.9(0.4) \mathrm{a}$ & $16.5(0.4) \mathrm{a}$ \\
$\quad$ Containerized & $21.4(0.3) \mathrm{b}$ & $17.9(0.4) \mathrm{b}$ \\
$\quad$ Bare-root & & \\
\hline ANOVA (fixed effects) & $p=0.298$ & $p=0.029$ \\
Scarification (S) & $p<0.001$ & $p<0.001$ \\
Vegetation (V) & $p=0.860$ & $p=0.247$ \\
S $\times$ V & $p=0.005$ & $p<0.001$ \\
Stock type (T) & $p=0.400$ & $p=0.103$ \\
$\mathrm{~S} \times \mathrm{T}$ & $p=0.294$ & $p=0.136$ \\
$\mathrm{~V} \times \mathrm{T}$ & $p=0.212$ & $p=0.560$ \\
$\mathrm{~S} \times \mathrm{V} \times \mathrm{T}$ & & \\
\hline $\mathrm{D}$ & &
\end{tabular}

Data are presented as MEAN (SE). For a given combination of treatments with respect to each site, means followed by the same letter are not significantly different, according to the Fisher's protected LSD test.

characterized by a total height at least equal or greater than large bare-root seedlings. At LC, large container-grown seedlings planted in unscarified plots reached the highest thirdyear height. After three growing seasons, survival was above $97 \%$ for all treatment combinations.

\subsection{Third-year diameter}

Soil scarification did not influence GLD of the seedlings planted at RP (Tab. II). At LC, a significant negative but minor effect of soil scarification on GLD was observed (Tab. II). At both experimental sites, competing vegetation had by far the most noticeable impact on GLD. The presence of vegetation reduced third-year seedling GLD by 41 and $32 \%$ at RP and LC, respectively. Large container-grown seedlings planted at RP had a larger third-year diameter than large bare-root stock; the effect was reversed at LC.

\subsection{Seedling competitive status and competing vegetation}

For the seedlings planted at both sites, neither soil scarification nor stock type influenced the quantity of light reaching the mid-upper crown of the seedlings (data not shown) ( $p \geq$ 0.361 at RP and $p \geq 0.441$ at LC). During their third year, seedlings planted in competition plots at RP received an aver-
Table III. Source of variation and associated $p$-values for predawn and midday xylem water potentials (XWP) of black spruce seedlings planted at Ruisseau Plourde (RP) and Lac Castor (LC), for years 1 to 3 .

\begin{tabular}{|c|c|c|c|c|}
\hline \multirow{2}{*}{$\begin{array}{l}\text { Source of variation } \\
\text { (fixed effects) }\end{array}$} & \multicolumn{2}{|c|}{ Ruisseau Plourde } & \multicolumn{2}{|c|}{ Lac Castor } \\
\hline & $\begin{array}{l}\text { Predawn } \\
\text { XWP }\end{array}$ & $\begin{array}{l}\text { Midday } \\
\text { XWP }\end{array}$ & $\begin{array}{l}\text { Predawn } \\
\text { XWP }\end{array}$ & $\begin{array}{l}\text { Midday } \\
\text { XWP }\end{array}$ \\
\hline \multicolumn{5}{|l|}{ Year 1} \\
\hline Scarification (S) & 0.374 & 0.115 & 0.114 & 0.221 \\
\hline Stock type (T) & $<0.001$ & $<0.001$ & $<0.001$ & $<0.001$ \\
\hline $\mathrm{S} \times \mathrm{T}$ & 0.292 & 0.799 & 0.005 & 0.976 \\
\hline Time (TI) & $<0.001$ & $<0.001$ & $<0.001$ & $<0.001$ \\
\hline $\mathrm{S} \times \mathrm{TI}$ & 0.120 & 0.474 & 0.324 & 0.722 \\
\hline $\mathrm{T} \times \mathrm{TI}$ & $<0.001$ & $<0.001$ & $<0.001$ & 0.018 \\
\hline $\mathrm{S} \times \mathrm{T} \times \mathrm{TI}$ & 0.770 & 0.753 & 0.466 & 0.858 \\
\hline \multicolumn{5}{|l|}{ Year 2} \\
\hline Scarification (S) & 0.797 & 0.028 & 0.413 & 0.039 \\
\hline Stock type (T) & 0.037 & 0.001 & 0.020 & 0.288 \\
\hline $\mathrm{S} \times \mathrm{T}$ & 0.866 & 0.312 & 0.465 & 0.237 \\
\hline Time (TI) & $<0.001$ & $<0.001$ & $<0.001$ & $<0.001$ \\
\hline $\mathrm{S} \times \mathrm{TI}$ & 0.754 & 0.890 & 0.763 & 0.887 \\
\hline $\mathrm{T} \times \mathrm{TI}$ & 0.019 & 0.003 & 0.463 & 0.822 \\
\hline $\mathrm{S} \times \mathrm{T} \times \mathrm{TI}$ & 0.910 & 0.427 & 0.657 & 0.377 \\
\hline \multicolumn{5}{|l|}{ Year 3} \\
\hline Scarification (S) & 0.583 & 0.770 & 0.472 & 0.091 \\
\hline Stock type (T) & 0.045 & 0.759 & 0.153 & 0.735 \\
\hline $\mathrm{S} \times \mathrm{T}$ & 0.622 & 0.019 & 0.053 & 0.110 \\
\hline Time (TI) & $<0.001$ & $<0.001$ & $<0.001$ & 0.022 \\
\hline $\mathrm{S} \times \mathrm{TI}$ & 0.294 & 0.435 & 0.984 & 0.169 \\
\hline $\mathrm{T} \times \mathrm{TI}$ & 0.901 & 0.265 & 0.475 & 0.947 \\
\hline $\mathrm{S} \times \mathrm{T} \times \mathrm{TI}$ & 0.533 & 0.587 & 0.339 & 0.063 \\
\hline
\end{tabular}

age of $34 \%$ of full sunlight while they received $51 \%$ of full sunlight at LC. At both sites, soil scarification did not significantly affect vegetation density of any of the vegetation categories (data not shown).

\subsection{Foliar nutrient concentration}

Soil scarification did not influence third-year (October) foliar nutrient concentration of current-year needles on either sites (data not shown) ( $p \geq 0.502)$. At both RP and LC sites, competing vegetation had a negative impact on foliar-N concentration, reducing it by $23 \%$ when compared to competition-free plots $(p<0.001)$. Seedling foliar-P and foliar-Ca concentrations were reduced in the presence of competing vegetation by up to $13 \%$ and $30 \%$, respectively, compared to vegetation-free plots $(p \leq 0.006)$. The presence of competing vegetation had a positive impact on foliar-K concentration at both sites $(p \leq$ 0.002 ). Overall, large bare-root and containerized seedlings presented similar foliar nutrient levels at the end of the third growing season. 

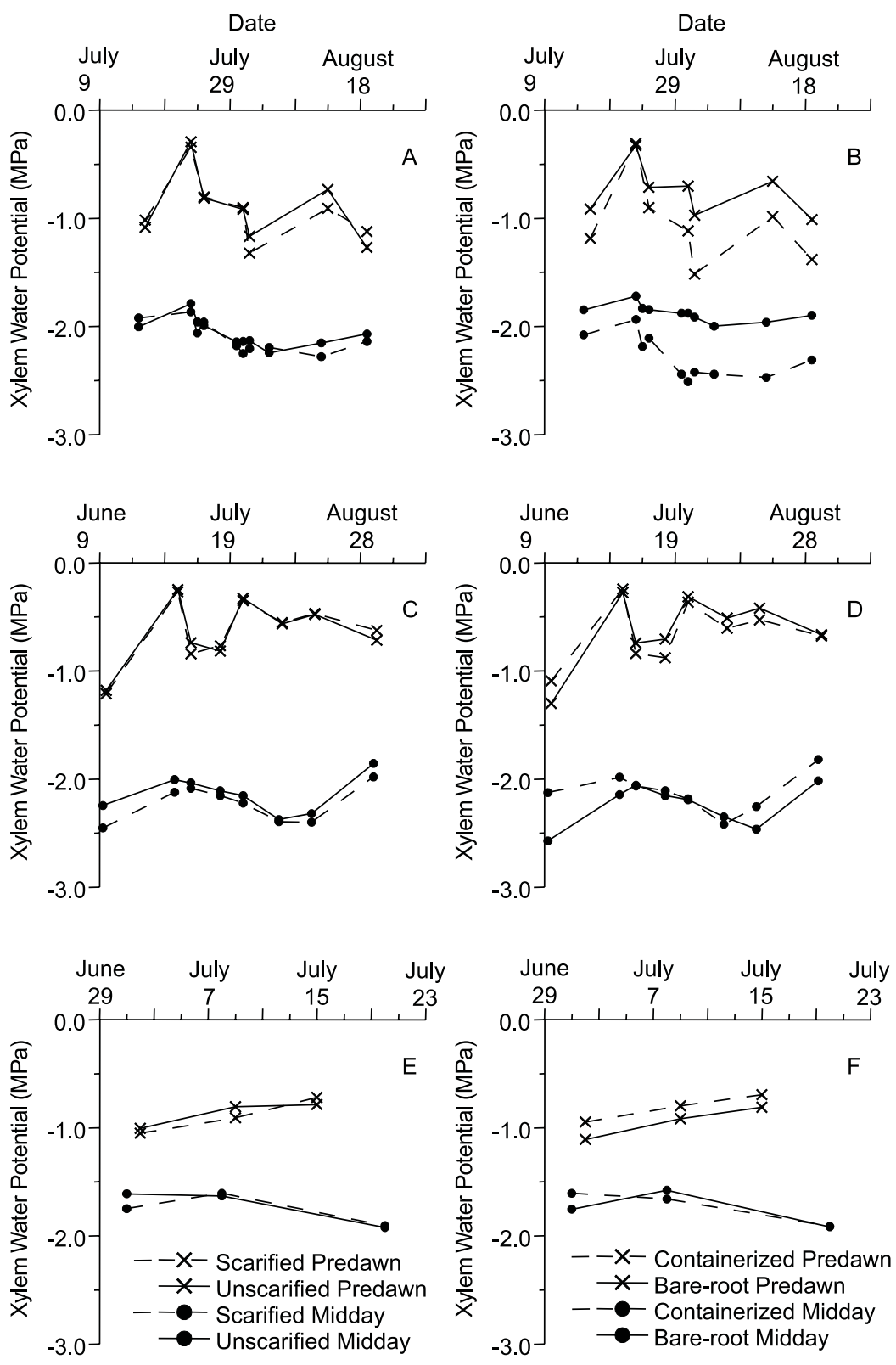

Figure 2. Effect of scarification and stock type on predawn and midday xylem water potentials (XWP) of black spruce seedlings planted at Ruisseau Plourde (RP) in 1997 (A, B), 1998 (C, D), and 1999 (E, F). See Table III for $p$-values. Legend presented in $\mathrm{E}$ is also valid for $\mathrm{A}$ and $\mathrm{C}$. Legend presented in $\mathrm{F}$ is also valid for $\mathrm{B}$ and $\mathrm{D}$. For clarity convenience, main soil scarification and stock type effects on midday XWP are presented separately for 1999 (E, F) in spite of a significant interaction between the two treatments. Measurements were performed in plots with competing vegetation.

\subsection{Xylem water potential}

During the first growing season, soil scarification did not affect either predawn or midday XWP of black spruce seedlings planted at RP (Tab. III and Fig. 2A). However, significant differences between the seasonal water status profiles of the two stock types were observed (Tab. III and Fig. 2B). Large containerized seedlings were characterized by a consistently lower water potential (more negative) than large bareroot seedlings. Similar results were obtained at LC during the first year (see Tab. III for $p$-values, data not shown).

During the second growing season, midday measurements revealed that seedlings planted in scarified plots of both sites had lower water potential than seedling planted in control plots, regardless of stock type (Tab. III and Fig. 2C for RP site). At RP, stock type XWP seasonal profiles were significantly different (Tab. III and Fig. 2D); large containerized seedlings presented less negative midday XWP than large bare-root seedlings.

At both sites, soil scarification did not modify third-year predawn XWP of the seedlings (Tab. III and Fig. 2E for RP site). Large containerized seedlings planted at RP showed less negative predawn XWP than large bare-root seedling (Fig. 2F). This effect was not significant at LC, but the same tendency was observed. Midday XWP of seedlings at LC was not influenced by scarification or stock type (Tab. III). At RP, stock type and scarification interacted to influence midday 
XWP. On scarified plots, large bare-root seedlings experienced a more negative water potential than large containerized seedlings, while the opposite phenomena was observed on control plots.

\subsection{Soil temperature}

During the first growing season, soil temperature was generally not significantly affected by soil scarification (data not shown). Soil temperature was enhanced by scarification ( $p=$ $0.005)$ and reduced by competing vegetation $(p \leq 0.009)$, during the first half of the third growing season at RP. Although significant, differences were small (around $1.5^{\circ} \mathrm{C}$ ). Scarification did not significantly influence third-year soil temperature at LC ( $p \geq 0.243$ ), but again warmer soil conditions were measured in competition-free plots from mid-July to earlySeptember $(p<0.001)$.

At RP, soil scarification did not influence first- and secondyear soil temperature sums, but significantly enhanced thirdyear temperature sum by $3.5 \%(p=0.017)$ (data not shown). At LC, scarification had a beneficial effect of $6 \%$ on first-year temperature sum ( $p=0.013)$, but only in competition-free plots (scarification $\times$ vegetation, $p=0.004$ ). No effect of scarification on the second- and third-year temperature sums was noted at LC. The presence of competing vegetation reduced RP third-year temperature sum by $10 \%(p<0.001)$. This competition effect was observed at LC for each of the first three years, with reductions ranging from 7 to $9 \%(p<0.046)$ (data not shown).

\subsection{Volumetric soil water content}

Scarification and competing vegetation did not modify volumetric soil water content at RP and LC during the first and second growing seasons (data not shown). Soil scarification did not modify third-year soil water content at either site $(p \geq$ $0.066)$. The presence of competing vegetation significantly reduced soil water content during the first half of the third growing season at RP $(p=0.035)$, and during the first part of the third growing season at LC $(p \leq 0.045)$.

\subsection{Nutrient sorption by resins}

Soil scarification reduced ammonium sorption by resins at RP during the second and third growing seasons (data not shown), and at LC during the first two growing seasons ( $p \leq$ 0.024) (Fig. 3). First-season nitrate sorption was enhanced by scarification at RP, when compared to unscarified plots $(p=$ $0.031)$, but reduced in the following years $(p \leq 0.002)$. A reduction in nitrate sorption by resins buried in scarified plots was also noted at LC during the second and third growing seasons $(p \leq 0.025)$. At RP, first-season phosphorus sorption was less in scarified plots than in unscarified plots $(p<0.001)$, with no significant difference detectable in the following years. Soil scarification did not significantly modify first-season phosphorus sorption at LC, but reduced second-year sorption of this nutrient $(p<0.001)$. Potassium sorption was negatively affected by soil scarification at RP during the first and second seasons, and at LC during the second and third seasons ( $p \leq$ 0.046).
Competing vegetation negatively affected ammonium sorption at RP (data not shown) ( $p \leq 0.041$ ), but not at LC (Fig. 3). When compared with competition-free plots, nitrate sorption was generally lower when competing vegetation was present ( $p \leq 0.003$ ), with the exception of RP during the first and second years, and LC during the first growing season. Third-year phosphorus sorption was higher at both RP and LC when competitors were present, compared to competition-free plots $(p \leq 0.021)$. Potassium sorption by resins was not significantly affected by competition at LC.

In the undisturbed adjacent forest stand, seasonal ammonium and nitrate sorption by resins varied from 0.1 to $0.5 \mathrm{mg}$ $\mathrm{bag}^{-1}$, and from 0.1 to $0.3 \mathrm{mg} \mathrm{bag}^{-1}$, respectively. Thus, clearcutting enhanced soil ammonium and nitrate sorption at both sites and during the first three growing seasons by factors up to 5 and 25, respectively. Phosphorus and potassium sorption were at least three times greater in the undisturbed forest stand than in the experimental plantations, with seasonal adsorption values ranging from 0.3 to $0.7 \mathrm{mg} \mathrm{bag}^{-1}$, and from 15.5 to $25.8 \mathrm{mg} \mathrm{bag}^{-1}$, respectively.

\section{DISCUSSION}

For most of the studied variables, treatment effects were additive (i.e. no interaction). We therefore discuss main treatment effects separately.

\subsection{Impacts of soil scarification}

The overall effect of soil scarification on spruce establishment was null or slightly negative on both experimental sites. Soil scarification did not influence third-year spruce foliar concentration and light availability to the planted seedlings. However, soil scarification had a small negative effect on spruce third-year height and GLD and showed a small positive effect on soil temperature and water content. A surface organic layer of about $3-\mathrm{cm}$ thickness characterized the soil at both experimental sites. Benefits from soil scarification on seedling growth (height, GLD) are less likely to occur on sites with thin humus with weak insulating properties, compared to boreal sites with thick organic layers, since these are mainly related to increased soil thermal properties and to the removal of the insulating mat of organic material [43]. Other studies have found minimal responses in tree growth and nutrition after scarification of sites with thin humus layers. White spruce foliar nutrient status was minimally affected over the first three years after disc trenching of Albertan sites (Canada) with humus of 5- to 7-cm depth [32]. In an experiment conducted on three sites varying in their soil characteristics, Brand [7] noted that soil scarification is most effective at stimulating tree growth where the original forest floor layers are thickest. No effect of Donaren disc trenching is observed on black and white spruce growth on mixedwood sites of southern Manitoba [62] with a humus thickness of 5 to $12 \mathrm{~cm}$ (G.G. Wang, pers. comm.).

Harvesting activities greatly influenced nutrient sorption by resins. At the experimental sites, we measured enhanced mineral nitrogen availability, compared to the undisturbed forest stand. Harvesting effects on nutrient availability were likely caused by modification of soil temperature, soil moisture, and 

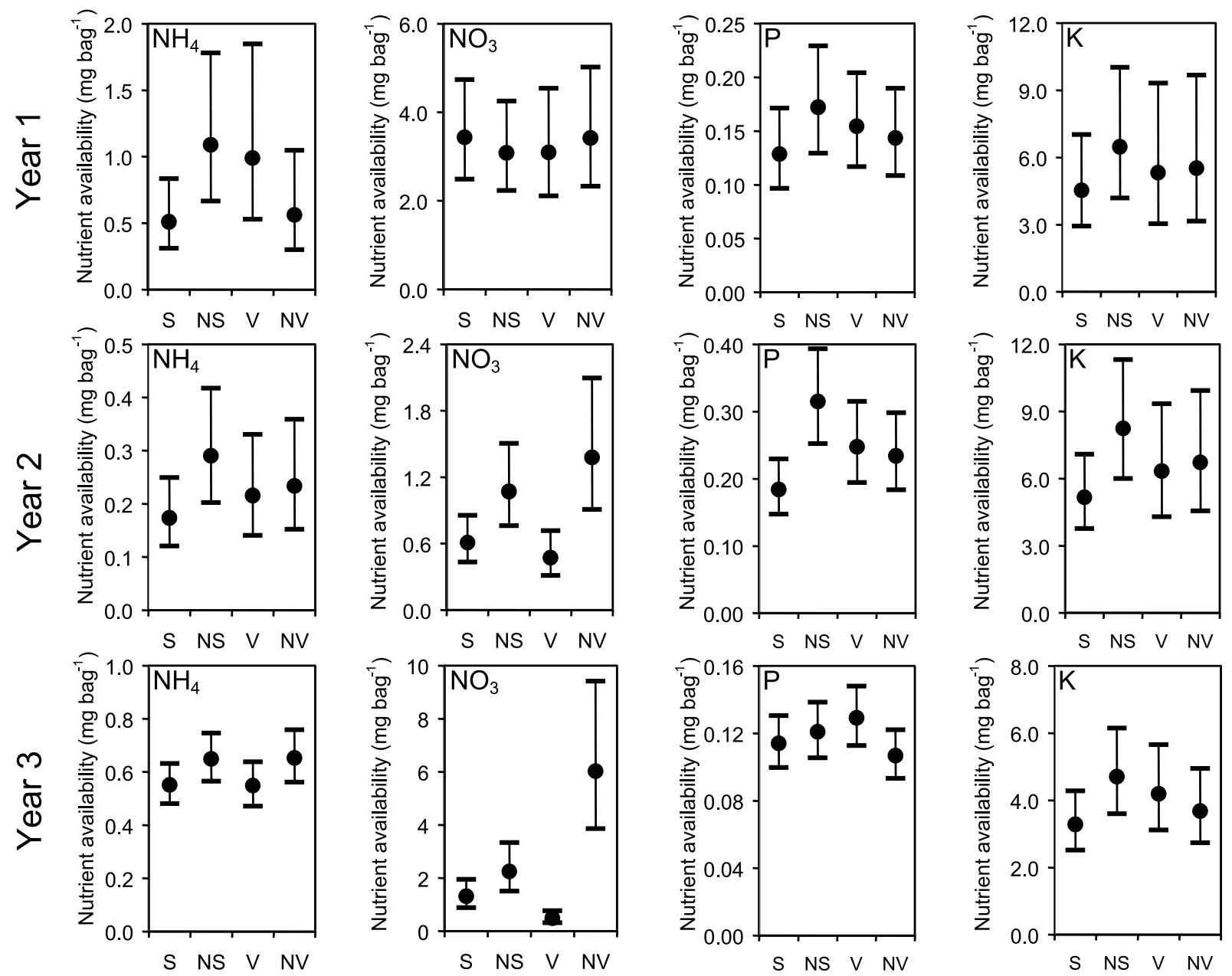

Figure 3. Effect of scarification and competing vegetation on soil nutrient availability at Lac Castor (LC) during the first three growing seasons, as estimated with an exchange resin bag method. Analyses were performed on natural-log transformed data. Figures represent back-transformed means $\pm 2 \mathrm{SE}$. $\mathrm{S}=$ with scarification; $\mathrm{NS}=$ no scarification; $\mathrm{V}=$ with vegetation; $\mathrm{NV}=$ no vegetation.

plant nutrient assimilation after tree removal [46, 47]. In scarified plots within the experimental plantations, the roughly mixed state of the organic and mineral material that was deposited beside the trench may have promoted increased rates of mineralization [43]. Increased ammonium availability after higher mineralization rates may have also stimulated nitrifier activity, and thus nitrate availability during the first season. Reduced nitrate availability during the following years could be the result of increased leaching [59], a phenomenon potentially exacerbated by the absence of competing vegetation at time of planting [31]. However, leaching was not monitored in the present experiment.

Light has been identified as the main limiting environmental resource to planted conifer growth in the sub-boreal mixedwoods of Québec [21, 24]. Scarification did not influence light availability at the tree seedling level. The procedure used to measure light availability simultaneously integrated height and density of the competing species and height of the tree seedlings [19]. Soil scarification did not increase seedling height, even in competing vegetation-free plots, and the treatment did not modify the competing vegetation complex (density and composition) to an extent susceptible to affect light availability to the planted conifers. We hypothesize that this absence of scarification effect on vegetation characteristics three years after tree planting is a consequence of (i) the short delay between clear-cut harvesting and scarification treatments (less than one year), so the site was scarified prior to vegetation establishment; (ii) the lack of scarification effects on environmental conditions (soil temperature and moisture); and (iii) the low extent to which soil nutrient availability was modified by the scarification treatment.

Soil scarification slightly aggravated the water stress experienced by both stock types during their second year of growth, and by bare-root stock during the third season. Although statistically significant, differences are not biologically meaningful. Bassman [3] measured lower XWP in Picea engelmannii $\times$ glauca seedlings planted in site-prepared plots, compared to control plots with a thin $(5 \mathrm{~cm})$ humus layer. In this latter study, 
a positive impact of mounding on soil temperature in the rooting zone (5-cm depth) was noted, but was negated by an accelerated drying of the exposed mineral surface. In contrast, Grossnickle and Heikurinen [16] observed that seasonal water stress of newly planted white spruce seedlings is minimized in site-prepared plots, compared to control plots with humus layers thinner than $18 \mathrm{~cm}$. Contrasting results among studies can arise from differences in the environmental conditions between experiments and from the nature of the specific scarification technique, which can create an array of microsite conditions even within a single type of treatment [57].

\subsection{Impacts of competing vegetation}

The presence of competing vegetation had marginal impacts on seedling total height after three growing seasons, a phenomena frequently reported in competition studies [14, 24, $36,41]$. We attribute these minimal effects of competition to the contrasting behaviour of apical and cambial meristems in terms of sink strength and growth phenology [30]. Competing vegetation greatly reduced third-year GLD. Jobidon et al. [25], Burgess et al. [10] and Munson et al. [38] also observed high sensitivity of spruce diameter growth to the presence of competing vegetation. The cambium being a relatively weak sink in the tree seedling, as compared to the apical meristems, little stored carbohydrate is available for diameter growth during shoot elongation [30]. Thus, radial growth depends on current products of photosynthesis, which are greatly reduced under low light availability [51].

Nearly absent during the first year, the negative competing vegetation effects on soil temperature and soil temperature sum were clear during the third growing season. At the ground level, interception of incoming radiation by vegetation frequently reached $95 \%$. Along with albedo and surface roughness, vegetation cover is one of the surface factors influencing soil temperature by absorbing solar radiation, and shading the ground surface [55]. In a five-year study of the influence of competing vegetation on soil temperature seasonal profiles, Jobidon [24] noted similar unfavourable impact of non-crop vegetation on root-zone temperature, which was increasingly affected with higher competing vegetation leaf area index. Nilsson and Örlander [41] report similar effects of vegetation on grass-dominated clearcuts in Sweden.

Competing vegetation had a strong negative impact on seedling third-year foliar-N concentration. Soil nutrient availability was generally higher in competition-free plots, compared to weedy plots. This is attributed to nutrient uptake by competing vegetation that is well adapted to early-successional site conditions [22]. Nutrient competition may thus have played a role, with light interception, in competing vegetation effects on growth. Jobidon [24] observed decreases in white spruce foliar- $\mathrm{N}$ in the presence of competing vegetation; decreases of 29 and $26 \%$, two and three years after planting, respectively, were observed, with levels in the critical range for this species (13-15 $\left.\mathrm{g} \mathrm{kg}^{-1}\right)$ [37].

\subsection{Impacts of stock type}

After three years, large containerized seedlings were slightly taller than large bare-root stock and had similar GLD.
Thus, the large containerized stock overcame the GLD size differences observed at time of planting, likely a result related to higher absolute growth rates over the first three years. Greater initial growth for other types of container-grown seedlings was observed previously [1,9]. In the present experiment, the large containerized seedlings had higher initial nutritional status than the large bare-root stock (foliar-N concentrations of $1.64 \%$ and $1.48 \%$ for the former and the latter, respectively), as a result of their nursery cultivation regime (M. Tourigny, pers. comm.). Mineral nutrient status acts as a link in the feedback loop relating seedling root growth and photosynthesis, which are two key process determining seedling establishment success and growth [8]. We hypothesize that the better nutrient status of the large containerized stock at time of planting has stimulated higher rates of photosynthesis [11].

We believe that differences in initial root system characteristics are one of the factors responsible for the more negative water potential that the containerized seedlings experienced during the first growing season, compared to the bare-root seedlings. Available soil water, root system characteristics (size, distribution, and hydraulic conductivity), and root-soil contact influence the seedling's ability to take up water [15]. For example, for containerized Scots pine [Pinus sylvestris L.] seedlings, the most important resistance to water-flow in the soil-plant pathway is located in the peat soil surrounding the roots [42]. Bernier [4] and Bernier et al. [5] also reported low soil hydraulic conductivity of peat-based growing medium under low soil water content conditions and its effect on seedling water stress.

\subsection{Management implications}

We carried out this study at two experimental sites with different soil characteristics, established with a one-year interval. For most of the studied variables, we obtained similar results at both sites. It greatly reduces the possibility that we observed responses related to site or meteorological conditions. Seedling transplanting shock, as evaluated by the water stress, was less for the large bare-root stock compared to the large containerized seedlings during the first growing season; a reverse pattern was observed the ensuing years. After three years, the large container stock presented improved growth compared to the large bare-root stock. Soil scarification did not benefit growth and nutrition of the planted seedlings and had no marked influence on soil water content, temperature, nutrient availability, and did not influence the characteristics of the vegetation complex, both in terms of density and composition. Enhanced nutrient availability was first a consequence of clear-cut activities. Scarification had an additive effect but likely promoted nutrient leaching, compared to unscarified plots. Competing vegetation had the strongest impact on seedling establishment, regardless of the large stock type used.

For the early-stage of plantation establishment in the subboreal mixedwoods of Québec, our results have the following silvicultural implications. First, the general additive responses of nursery practices for breeding large spruce seedlings and of silvicultural activities indicate that soil scarification and release treatments to be done on a site can be planned independently from the large stock type used. Secondly, soil scarification by 
disc trenching of sites characterized by thin humus layers is not required for large spruce seedling establishment, evaluated in terms of transplanting shock and growth. Prescription of mechanical soil scarification should therefore be based on other considerations, such as facilitating practical reforestation work. Thirdly, efforts should be oriented towards early diagnosis of competing vegetation effects followed by release treatments, the potential growth loss to competition being obvious, even with use of large containerized or large bare-root stock. However, in a context where chemical herbicide are no longer an operational option in Québec, the use of large seedling stock will help reduce the need for repeated release treatments and therefore presents an advantage to the use of standard-size seedlings [26]. Finally, the use of either large containerized or large bare-root stock has only a minor influence on plantation success, from the strict silvicultural point of view (inherent growth and growth response to silvicultural activities). Seedling availability, ease of transportation, handling and planting remain other important factors influencing manager's choice of large stock type.

Acknowledgements: We thank Jacques Carignan, Réjean Poliquin, Francis Cadoret and summer undergraduate students for their contribution in field work. We acknowledge the help of Normand Gendron of the Ministère des Ressources naturelles, de la Faune et des Parcs (MRNFP) and Gérald Baril of Richard Pelletier et Fils Inc. for their assistance and financial support throughout this research project. We also thank the staff of the MRNFP laboratory for all the chemical analyses. We are grateful to Vincent Roy and two anonymous reviewers for their valuable comments. This research was funded through a research grant to A. Munson from the Action concertée FCAR - Fonds forestier; we also appreciate funding from Forêt Québec (MRNFP) through the research project 365S.

\section{REFERENCES}

[1] Alm A.A., Black and white spruce planting in Minnesota: container vs. bareroot and fall vs spring planting, For. Chron. 59 (1983) 189191.

[2] Auchmoody L.R., Nitrogen fertilization stimulates germination of dormant pin cherry seed, Can. J. For. Res. 9 (1979) 514-516.

[3] Bassman J.H., Influence of two site preparation treatments on ecophysiology of planted Picea engelmannii $\times$ glauca seedlings, Can. J. For. Res. 19 (1989) 1359-1370.

[4] Bernier P.Y., Soil texture influences seedling water stress in more ways than one, Tree Plant. Notes 43 (1992) 39-42.

[5] Bernier P.Y., Stewart J.D., Gonzalez A., Effects of the physical properties of sphagnum peat on the water stress in containerized Picea mariana seedlings under simulated field conditions, Scand. J. For. Res. 10 (1995) 184-189.

[6] Boucher J.F., Wetzel S., Munson A.D., Leaf level response of planted eastern white pine (Pinus strobus L.) seven years after intensive silvicultural treatments, For. Ecol. Manage. 107 (1998) 291-307.

[7] Brand D.G., The establishment of boreal and sub-boreal conifer plantations: an integrated analysis of environmental conditions and seedling growth, For. Sci. 37 (1991) 68-100.

[8] Burdett A.N., Physiological processes in plantation establishment and the development of specifications for forest planting stock, Can. J. For. Res. 20 (1990) 415-427.

[9] Burdett A.N., Herring L.J., Thompson C.F., Early growth of planted spruce, Can. J. For. Res. 14 (1984) 644-651.
[10] Burgess D., Baldock J.A., Wetzel S., Brand D.G., Scarification, fertilization and herbicide treatment effects on planted conifers and soil fertility, Plant Soil 168/169 (1995) 513-522.

[11] Field C., Allocating leaf nitrogen for the maximization of carbon gain: leaf age as a control on the allocation program, Oecologia 56 (1983) 341-347.

[12] Flemming R.L., Black T.A., Adams R.S., Site preparation effects on Douglas-fir and logepole pine water relations following planting in a pinegrass-dominated clearcut, For. Ecol. Manage. 83 (1996) 47-60.

[13] Gingras B.M., Richard S., Bilan du développement des récipients à parois ajourées : culture des semis en pépinière et performance en plantation comparative, Mémoire de recherche forestière 130, Direction de la recherche forestière, Forêt Québec, Ministère des Ressources naturelles, 1999.

[14] Groot A., Effects of shelter and competition on the early growth of planted white spruce (Picea glauca), Can. J. For. Res. 29 (1999) 1002-1014.

[15] Grossnickle S.C., Ecophysiology of Northern Spruce Species: The Performance of Planted Seedlings, NRC Research Press, Ottawa, ON, 2000.

[16] Grossnickle S.C., Heikurinen J., Site preparation: Water relations and growth of newly planted jack pine and white spruce, New For 3 (1989) 99-123.

[17] Hudson J.P., Propagation of plants by root cuttings. I. Regeneration of raspberry root cuttings, J. Hortic. Sci. 29 (1954) 27-43.

[18] Jobidon R., Short-term effect of three mechanical site preparation methods on species diversity, Tree Plant. Notes 41 (1990) 39-42.

[19] Jobidon R., Measurement of light transmission in young conifer plantations: a new technique for assessing herbicide efficacy, North. J. Appl. For. 9 (1992) 112-115.

[20] Jobidon R., Nitrate fertilization stimulates emergence of red raspberry (Rubus idaeus L.) under forest canopy, Fertil. Res. 36 (1993) 91-94.

[21] Jobidon R., Light threshold for optimal black spruce (Picea mariana) seedling growth and development under brush competition, Can. J. For. Res. 24 (1994) 1629-1635.

[22] Jobidon R., Autécologie de quelques espèces de compétition d'importance pour la régénération forestière au Québec : revue de littérature, Mémoire de recherche forestière 117, Direction de la recherche forestière, Forêt Québec, Ministère des Ressources naturelles, 1995.

[23] Jobidon R., Pin cherry sucker regeneration after cutting, North. J. Appl. For. 14 (1997) 117-119.

[24] Jobidon R., Density-dependent effects of northern hardwood competition on selected environmental resources and young white spruce (Picea glauca) plantation growth, mineral nutrition, and stand structural development: a 5-year study, For. Ecol. Manage. 130 (2000) 77-97.

[25] Jobidon R., Charette L., Bernier P.Y., Initial size and competing vegetation effects on water stress and growth of Picea mariana (Mill.) BSP seedlings planted in three different environments, For. Ecol. Manage. 103 (1998) 293-305.

[26] Jobidon R., Roy V., Cyr G., Net effect of competing vegetation on selected environmental conditions and performance of four spruce seedling stock sizes after eight years in Québec (Canada), Ann. For. Sci. 60 (2003) 691-699.

[27] Kozlowski T.T., Water supply and tree growth. Part I: Water deficits, Forestry Abstracts 43 (1982) 57-95.

[28] Lamhamedi M.S., Bernier P.Y., Hébert C., Jobidon R., Physiological and growth response of three sizes of containerized Picea mariana seedlings outplanted with and without vegetation control, For. Ecol. Manage. 110 (1998) 13-23.

[29] Langvall O., Nilsson U., Örlander G., Frost damage to planted Norway spruce seedlings - influence of site preparation and seedling type, For. Ecol. Manage. 141 (2001) 223-235. 
[30] Lanner R.M., On the insensitivity of height growth to spacing, For. Ecol. Manage. 13 (1985) 143-148.

[31] Likens G.E., Bormann F.H., Johnson N.M., Fisher D.W., Pierce R.S., Effects of forest cutting and herbicide treatment on nutrient budgets in the Hubbard Brook Watershed-ecosystem, Ecol. Monogr. 40 (1970) 23-47.

[32] Macdonald S.E., Schmidt M.G., Rothwell R.L., Impacts of mechanical site preparation on foliar nutrients of planted white spruce seedlings on mixed-wood boreal forest sites in Alberta, For. Ecol. Manage. 110 (1998) 35-48.

[33] McDonald P.M., Container seedlings outperform barefoot stock: Survival and growth after 10 years, New For. 5 (1991) 147-156.

[34] Milliken G.A., Johnson D.E., Analysis of Messy Data. Volume 1: Designed Experiments, Van Nostrand Reinhold, New York, 1984.

[35] Ministère des Ressources naturelles du Québec, Une stratégie : aménager pour mieux protéger les forêts, Publication FQ94-3051, Gouvernement du Québec, 1994.

[36] Morris D.M., MacDonald G.B., McLain K.M., Evaluation of morphological attributes as response variables to perennial competition for 4-year-old black spruce and jack pine seedlings, Can. J. For. Res. 20 (1990) 1696-1703.

[37] Morrison I.K., Mineral nutrition of conifers with special reference to nutrient status interpretation: a review of literature, Publication 1343, Department of the Environment, Canadian Forestry Service, 1974.

[38] Munson A.D., Margolis H.A., Brand D.G., Intensive silvicultural treatment: impact on soil fertility and planted conifer response, Soil Sci. Soc. Am. J. 57 (1993) 246-255.

[39] Newton M., Cole E.C., White D.E., Tall planting stock for enhanced growth and domination of brush in the Douglas-fir region, New For. 7 (1993) 107-121.

[40] Nilsson U., Örlander G., Effects of regeneration methods on drought damage to newly planted Norway spruce seedlings, Can. J. For. Res. 25 (1995) 790-802.

[41] Nilsson U., Örlander G., Vegetation management on grassdominated clearcuts planted with Norway spruce in southern Sweden, Can. J. For. Res. 29 (1999) 1015-1026.

[42] Örlander G., Due K., Location of hydraulic resistance in the soilplant pathway in seedlings of Pinus sylvestris L. grown in peat, Can. J. For. Res. 16 (1986) 115-123.

[43] Örlander G., Gemmel P., Hunt J., Site Preparation: A Swedish Overview, FRDA Report 105, British Columbia Ministry of Forests, 1990.

[44] Örlander G., Nilsson U., Hallgren J.E., Griffith J.A., Competition for water and nutrients between ground vegetation and planted Picea abies, N.Z. J. For. Sci. 26 (1996) 99-117.

[45] Parkinson J.A., Allen S.E., A wet oxydation procedure suitable for the determination of nitrogen and mineral nutrients in biological material, Commun. Soil Sci. Plant Anal. 6 (1975) 1-11.
[46] Prescott C.E., Effects of clearcutting and alternative silvicultural systems on rates of decomposition and nitrogen mineralization in a coastal montane coniferous forest, For. Ecol. Manage. 95 (1997) 253-260.

[47] Prescott C.E., Maynard D.G., Laiho R., Humus in northern forests: friend or foe?, For. Ecol. Manage. 133 (2000) 23-36.

[48] Prévost M., Effets du scarifiage sur les propriétés du sol, la croissance des semis et la compétition : revue des connaissances actuelles et perspectives de recherches au Québec, Ann. Sci. For. 49 (1992) 277-296.

[49] Prévost M., Effets du scarifiage sur les propriétés du sol et l'ensemencement naturel dans une pessière noire à mousses de la forêt boréale québécoise, Can. J. For. Res. 26 (1996) 72-86.

[50] Robitaille A., Saucier J.P., Paysages régionaux du Québec méridional, Gouvernement du Québec, Ministère des Ressources naturelles, Québec, QC, 1998.

[51] Salisbury F.B., Ross C.W., Plant Physiology, Wadsworth Publishing Company, Belmont, CA, 1992.

[52] Saucier J.P., Bergeron J.F., Grondin P., Robitaille A., Les régions écologiques du Québec méridional ( $3^{\mathrm{e}}$ version), Supplément de l'Aubelle 124, Ministère des Ressources naturelles du Québec, 1998.

[53] Seber G.A.F., Multivariate Observations, John Wiley and Sons, New York, NY, 1984.

[54] Soil Classification Working Group, The Canadian System of Soil Classification, 3rd ed., Publication 1646, Agriculture and AgriFood Canada, 1998.

[55] Spittlehouse D.L., Stathers R.J., Seedling Microclimate, Land Management Report 65, British Columbia Ministry of Forests, 1990.

[56] Steel R.G.D., Torrie J.H., Dickey D.A., Principles and Procedures of Statistics: A Biometrical Approach, Boston, MA, 1997.

[57] Sutton R.F., Mounding site preparation: a review of european and North American experience, New For. 7 (1993) 151-192.

[58] Thiffault N., Jobidon R., De Blois C., Munson A.D., Washing procedure for mixed-bed ion exchange resin decontamination for in situ nutrient adsorption, Commun. Soil Sci. Plant Anal. 31 (2000) 543-546.

[59] Vitousek P.M., Melillo J.M., Nitrate losses from disturbed forests: Pattern and mechanisms, For. Sci. 25 (1979) 605-619.

[60] Wagner R.G., Flynn J., Gregory R., Public perceptions of risk and acceptability of forest vegetation management alternatives in Ontario, For. Chron. 74 (1998) 720-727.

[61] Walstad J.D., Kuch P.J., Forest Vegetation Management for Conifer Production, John Wiley and Sons, New York, NY, 1987.

[62] Wang G.G., Siemens J.A., Keenan V., Philippot D., Survival and growth of black and white spruce seedlings in relation to stock type, site preparation and plantation type in southeastern Manitoba, For. Chron. 75 (2000) 775-782. 